\title{
A Review on Analytical methods: Levetiracetam
}

\section{Malla Krishna Prasad* and Mukthinuthalapati Mathrusri Annapurna}

Department of Pharmaceutical Analysis and Quality Assurance, GITAM Institute

of Pharmacy, GITAM (Deemed to be University), Visakhapatnam, Andhra Pradesh,

India

*Corresponding Author: Malla Krishna Prasad, Department of Pharmaceutical Analysis and Quality Assurance, GITAM Institute of Pharmacy, GITAM (Deemed to be University), Visakhapatnam, Andhra Pradesh, India.
Received: February 24, 2021

Published: March 09, 2021

(C) All rights are reserved by Malla Krishna

Prasad and Mukthinuthalapati Mathrusri Annapurna

\begin{abstract}
Levetiracetam is a second-generation anti-epileptic drug which belongs to pyrrolidone family with wide spectrum of action. In 1999 Levetiracetam was approved by US Food and Drug Administration as a broad spectrum antiepileptic drug. Levetiracetam is different from other older antiepileptic drugs in its structure with hydrophilic groups. The present review summarizes the analytical techniques used for the analysis of Levetiracetam.
\end{abstract}

Keywords: Levetiracetam; Antiepileptic Drug; Spectrophotometry; HPLC; LC-MS

\section{Introduction}

Levetiracetam is an anti-epileptic agent [1] and chemically known as (S)-2-(2-oxopyrrolidin-1-yl) butanamide (Figure 1) and it has a molecular formula $\left(\mathrm{C}_{8} \mathrm{H}_{14} \mathrm{~N}_{2} \mathrm{O}_{2}\right)$. Levetiracetam is very soluble in water and freely soluble in methanol and chloroform. In n-hexane Levetiracetam is insoluble practically. Levetiracetam acts by modulating the synaptic neurotransmitter release and by binding itself to synaptic vesicle protein SV2A in the brain. Levetiracetam was approved by the US FDA. Levetiracetam is absorbed completely after the oral administration and about $100 \%$ bioavailability was reported. Levetiracetam undergoes metabolism through enzymatic hydrolysis of acetamide group. Levetiracetam maintains a large margin of safety and no interactions were reported with other anticonvulsants [2] and due to this Levetiracetam is used as an adjunctive therapy for the treatment of epileptic seizures.

The authors have summarised the analytical methods developed for the quantification of Levetiracetam in the present review article. These analytical methods include spectrophotometry [36], HPLC [7-12], UPLC [13], UHPLC [14], HPTLC [15], LC-MS/MS
$[16,17]$ and UPLC-MS/MS [18] for the estimation of Levetiracetam in pharmaceutical formulations and biological fluids such as human plasma and human serum (Table 1).

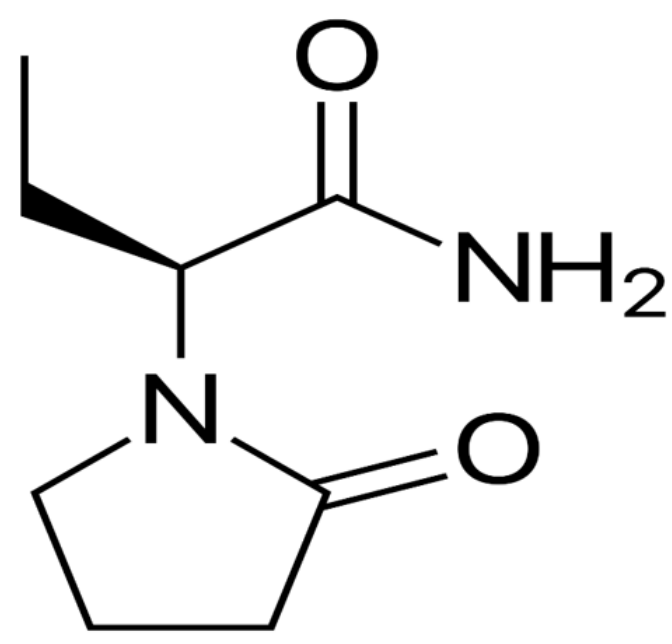

Figure 1: Structure of Levetiracetam. 


\begin{tabular}{|c|c|c|c|c|}
\hline Reagent/Mobile phase (v/v) & $\lambda(\mathrm{nm})$ & $\begin{array}{l}\text { Linearity } \\
(\mu \mathrm{g} / \mathrm{ml})\end{array}$ & Remarks & Ref \\
\hline \multicolumn{5}{|c|}{ Spectrophotometric methods } \\
\hline Water & 209 & $2-10$ & & 3 \\
\hline 2-Chloro phenyl hydrazine and & 560 & - & & 4 \\
\hline $2 \mathrm{ml}(0.25 \%)$ Anthranilic acid & 485 & & & \\
\hline 2,4- Dinitrophenylhydrazine & 455 & $30-130$ & & 5 \\
\hline Glacial acetic acid & 221 & $30-90$ & & 6 \\
\hline \multicolumn{5}{|c|}{ Liquid chromatographic methods } \\
\hline $\begin{array}{l}\text { Potassium dihydrogen phosphate and sodium 1-heptane } \\
\text { sulphonate buffer ( } \mathrm{pH} \text { adjusted to } 2.8 \text { with ortho phosphoric } \\
\text { acid): Acetonitrile }(90: 10)\end{array}$ & 215 & $45-270$ & HPLC & 7 \\
\hline $\begin{array}{l}\text { Acetonitrile: water } \\
\text { (Gradient mode) Internal standard }\end{array}$ & 205 & $2.5-29.7$ & $\begin{array}{l}\text { HPLC and GLC } \\
\text { Human serum }\end{array}$ & 8 \\
\hline $\begin{array}{l}\text { Acetonitrile: } 0.03 \mathrm{M} \text { potassium dihydrogen phosphate }(\mathrm{pH} \\
\text { adjusted to } 3.0 \text { with ortho phosphoric acid) (15: } 85)\end{array}$ & 210 & $20-240$ & HPLC & 9 \\
\hline $\begin{array}{l}0.05 \mathrm{M} \mathrm{KH}_{2} \mathrm{PO}_{4} \text { buffer ( } \mathrm{pH} \text { adjusted to } 3.0 \text { with ortho phos- } \\
\text { phoric acid): Methanol ( } 70: 30 \text { ) }\end{array}$ & 210 & $20-120$ & HPLC & 10 \\
\hline Water: acetonitrile $(90: 10)$ & 200 & $0.8-8.0$ & HPLC & 11 \\
\hline $\begin{array}{l}\text { Methanol: Ammonium acetate buffer (pH 4.0) (80:20) } \\
\text { Ritonavir (Internal standard) }\end{array}$ & 240 & $5-350$ & HPLC & 12 \\
\hline $\begin{array}{l}\text { Buffer }\left(\mathrm{KH}_{2} \mathrm{PO}_{4}+\text { Heptan sulphonic acid salt) }(\mathrm{pH} 2.4) \text { : Aceto- }\right. \\
\text { nitrile }(90: 10)\end{array}$ & 200 & $45-135$ & UPLC & 13 \\
\hline Acetonitrile: water (80: 20) Lamivudine (Internal standard) & 205 & $0.05-1$ & $\begin{array}{c}\text { UHPLC } \\
\text { Human serum } \\
\end{array}$ & 14 \\
\hline Toluene: Ethyl acetate: Methanol $(2: 1: 1)$ & 204 & $0.1-1.0$ & HPTLC & 15 \\
\hline \multicolumn{5}{|c|}{ Liquid chromatography-Mass spectrometric methods } \\
\hline $\begin{array}{l}5 \mathrm{mM} \text { Ammonium acetate (adjusted to } \mathrm{pH} 3.2 \text { with Glacial } \\
\text { acetic acid): Acetonitrile (20: 80) Clonazepam (Internal } \\
\text { standard) }\end{array}$ & - & $0.5-50$ & $\begin{array}{l}\text { LC-MS/MS Human } \\
\text { plasma }\end{array}$ & 16 \\
\hline $\begin{array}{l}0.1 \% \text { Formic acid in Ammonium acetate: Methanol (10: } 90 \text { ) } \\
\text { Lamivudine (Internal standard) }\end{array}$ & - & $0.50-80.0$ & $\begin{array}{l}\text { LC-MS/MS Human } \\
\text { plasma }\end{array}$ & 17 \\
\hline $\begin{array}{l}\text { [0.1\%formic acid - } 10 \mathrm{mM} \text { Ammonium formate }(\mathrm{pH} 3.5)] \\
{[0.1 \% \text { formic acid in methanol] (Gradient mode) }}\end{array}$ & - & $0.5-150$ & $\begin{array}{l}\text { UPLC-MS/MS } \\
\text { Human plasma }\end{array}$ & 18 \\
\hline
\end{tabular}

Table 1: Review of analytical methods for the determination of Levetiracetam.

\section{Conclusion}

Different analytical methods such as UV, HPLC, HPTLC, UPLC, UHPLC and hyphenated techniques such as GC-MS, LC-MS methods were reported for the estimation of Levetiracetam in bulk, pharmaceutical formulations and biological samples. This review article is very much useful for the readers for understanding the analytical techniques so far reported for the quantification of Levetiracetam. 


\section{Bibliography}

1. Martindale. The complete drug reference. 36th edition. Pha maceutical press, London. (2009): 488-489.

2. Yi ZM., et al. "Levetiracetam for epilepsy: an evidence map of efficacy, safety and economic profiles". Neuropsychiatric Di. ease and Treatment 15 (2018): 1-19.

3. Ravisankar P., et al. "A simple validated UV spectrophotome ric method for quantitative analysis of Levetiracetam in pharmaceutical dosage form". Indian Journal of Research in Pha macy and Biotechnology 3.5 (2015): 380-385.

4. Muralikrishna Ch., et al. "Spectrophotometric determin: tion of levetiracetam by developing coloured complexes wit 2-chlorophenylhydrazine and anthranilic acid". Asian Journal of Chemistry 24.4 (2012): 1855-1857.

5. Thanuja S., et al. "Spectrophotometric determination of Levet racetam using 2, 4-DNP in pharmaceutical dosage form". Ind American Journal of Pharmaceutical Research 4 (2014): 561565.

6. Madhu M., et al. "Development and validation of spectroscol ic method for estimation of Levetiracetam in tablet dosą form". Journal of Global Trends in Pharmaceutical Sciences 6. (2015): 2956-2962.

7. Valarmathy J., et al. "RP-HPLC method development and val dation for assay of Levetiracetam in tablet dosage form". $R_{\text {, }}$ search Journal of Pharmacy and Technology 1.3 (2008): 39! 397.

8. Vermeij TA., et al. "High-performance liquid chromatographi^ and megabore gas-liquid chromatographic determination ( Levetiracetam (ucb L059) in human serum after solid-phas extraction". Journal of Chromatography B 662.1 (1994): 13< 139.

9. Raju NA., et al. "Estimation of Levetiracetam in tablet dosage form by RP-HPLC". E-journal of Chemistry 5.S2 (2008): 10981102.

10. Rao AL and Jahnavi V. "A validated RP-HPLC method for the estimation of Levetiracetam in bulk and pharmaceutical formulations". E-Journal of Chemistry 7.2 (2010): 600-604.

11. Can NO and Goksel Arli. "Reversed-phase HPLC analysis of Levetiracetam in tablets using monolithic and conventional C18 silica columns". Journal of AOAC International 93.4 (2010): 1077-1085.
12. Prafulla Kumar Sahu., et al. "Development and validation of an RP-HPLC method for determination of Levetiracetamin bulk and pharmaceutical dosage forms". Analytical Chemistry, An Indian Journal 8.1 (2009): 34-38.

13. Parimal Patel., et al. "Development and validation of stabilityindicating UPLC method for estimation of Levetiracetam in bulk and pharmaceutical dosage form". Journal of Pharmacy Research 4.12 (2011): 4495-4497.

14. Mohammadi B., et al. "Simple and rapid ultra-high performance liquid chromatographic (UHPLC) method for the determination of Levetiracetam in human serum: Application to a bioequivalence study". African Journal of Pharmacy and Pharmacology 6.27 (2012): 2017-2022.

15. Bhattacharya., et al. "Development of a validated stability-indicating high-performance thin-layer chromatographic method for the quantification of Levetiracetam". Journal of Planar Chromatography 27.2 (2014): 132-139.

16. Jain DS., et al. "Determination of Levetiracetam in human plasma by liquid chromatography/electrospray tandem mass spectrometry and its application to bioequivalence studies". Rapid Communications in Mass Spectrometry 20.17 (2006): 2539-2547.

17. Jenjirattithigarn N., et al. "Determination of plasma Levetiracetam level by Liquid Chromatography-Tandem Mass Spectrometry (LC-MS-MS) and its application in pharmacokinetics studies in neonates". Journal of Chromatography B 1085 (2018): 13-20.

18. Blonk MI., et al. "Quantification of Levetiracetam in plasma of neonates by ultra-performance liquid chromatography-tandem mass spectrometry". Journal of Chromatography B 878.78 (2010): 675-681.

\section{Assets from publication with us}

- Prompt Acknowledgement after receiving the article

- Thorough Double blinded peer review

- Rapid Publication

- Issue of Publication Certificate

- High visibility of your Published work

Website: www.actascientific.com/ Submit Article: www.actascientific.com/submission.php Email us: editor@actascientific.com Contact us: +919182824667 